Article

\title{
Extension of the Upper Yellow River into the Tibet Plateau: Review and New Data
}

\author{
Zhengchen $\mathrm{Li}^{1}{ }^{1}$, Xianyan Wang ${ }^{1, *} \mathbb{C}$, Jef Vandenberghe ${ }^{2}(\mathbb{O})$ and Huayu $\mathrm{Lu}^{1}$ \\ 1 School of Geography and Ocean Science, Nanjing University, Nanjing 210023, China; \\ lizhch@smail.nju.edu.cn (Z.L.); huayulu@nju.edu.cn (H.L.) \\ 2 Department of Earth Sciences, Vrije Universiteit Amsterdam, De Boelelaan 1085, \\ 1081 HV Amsterdam, The Netherlands; jef.vandenberghe@vu.nl \\ * Correspondence: xianyanwang@nju.edu.cn
}

Citation: Li, Z.; Wang, X.;

Vandenberghe, J.; Lu, H. Extension of the Upper Yellow River into the Tibet

Plateau: Review and New Data.

Quaternary 2021, 4, 14. https://

doi.org/10.3390/quat4020014

Academic Editor: Pierre Antoine

Received: 8 February 2021

Accepted: 20 April 2021

Published: 25 April 2021

Publisher's Note: MDPI stays neutral with regard to jurisdictional claims in published maps and institutional affiliations.

Copyright: (c) 2021 by the authors. Licensee MDPI, Basel, Switzerland. This article is an open access article distributed under the terms and conditions of the Creative Commons Attribution (CC BY) license (https:/ / creativecommons.org/licenses/by/ $4.0 /)$.

\begin{abstract}
The Wufo Basin at the margin of the northeastern Tibet Plateau connects the upstream reaches of the Yellow River with the lowland catchment downstream, and the fluvial terrace sequence in this basin provides crucial clues to understand the evolution history of the Yellow River drainage system in relation to the uplift and outgrowth of the Tibetan Plateau. Using field survey and analysis of Digital Elevation Model/Google Earth imagery, we found at least eight Yellow River terraces in this area. The overlying loess of the highest terrace was dated at 1.2 Ma based on paleomagnetic stratigraphy (two normal and two reversal polarities) and the loess-paleosol sequence (12 loesspaleosol cycles). This terrace shows the connections of drainage parts in and outside the Tibetan Plateau through its NE margin. In addition, we review the previously published data on the Yellow River terraces and ancient large lakes in the basins. Based on our new data and previous researches, we conclude that the modern Yellow River, with headwaters in the Tibet Plateau and debouching in the Bohai Sea, should date from at least 1.2 Ma. Ancient large lakes (such as the Hetao and Sanmen Lakes) developed as exorheic systems and flowed through the modern Yellow River at that time.
\end{abstract}

Keywords: terraces; loess-paleosol sequence; Yellow River; magneto-stratigraphy; Northeastern Tibet Plateau

\section{Introduction}

The evolution of the Yellow River system is influenced by tectonic movements, climatic change, and human activity [1,2]. Meanwhile, the uplift of the Tibet Plateau reinforces the strength of the Asian Monsoon and plays an important role in global climate change [3]. In turn, rapid erosion may lead to a crust isostatic rebound and cause tectonic activity [4]. Moreover, the river network reorganization influenced by the tectonic activities, especially for larger river, may have affected biodiversity and even hominin migration $[5,6]$. As a significant geological event due to the collision between the Indian and Eurasian plates [7,8], the uplift of the Tibet Plateau has an important influence on global climate, and results in the aridification of northwestern China [9] and the re-configurated drainage systems in Asia. The Yellow River, the second-longest river in China, originates from the Tibet Plateau, flows through isolated basins including rift valleys and finally drains in the Bohai Sea (Figure 1). Unraveling the evolutionary history of the Yellow River may help understand the uplift of the Tibet Plateau.

The origin and evolutionary history of the Yellow River have been debated for a long time with different viewpoints. An hypothesis suggests the Yellow River might have extended from downstream to upstream through headward erosion into the Tibet Plateau, cutting across a series of alternating basin-mountain structures while capturing a series of endorheic drainage systems [10-12]. In such a scenario, some basins may have developed a spillover to join the Yellow River drainage $[10,11]$. The final extension of the entire Yellow River, from the Bohai Sea up to its present source, would have been of relatively young age 
(mid-Pleistocene). In a second scenario, it is suggested that the current Yellow River has already existed since at least pre-Quaternary and even pre-Neogene time, while paleo lakes developed in the basins as coexisting dammed lakes [13]. In the third scenario, the modern Yellow River finally formed after the Hetao or Sanmen paleo lakes finally went extinct, therefore implying a very young age of the Yellow River origin (late Pleistocene) [14].

To provide more relevant data, we focused on the fluvial terraces in the Wufo Basin at the northeastern boundary of the Tibet Plateau in this study. The Yellow River cuts through the Wufo Basin and flows into rift basins outside the Tibetan Plateau, such as the Yinchuan, Hetao, and Sanmen Basins (Figure 1). Thus, the Wufo Basin, which connects the upper Yellow River in the Tibet Plateau with downstream reaches outside the Tibet Plateau, is a prominent place to investigate the evolution history of the Yellow River into the Tibet Plateau (Figure 1). Until now, the data of terraces near the boundary between the Tibet Plateau and the Ordos block have remained lack. Thus, the correlation and connection history of the Yellow River drainage reaching inside and outside of the Tibet Plateau is still debated. These fluvial terraces are discussed in the framework of all available terrace information of the Yellow River [15-17] including the depositional history of the delta [18-20], and we aim to untangle the age of the connection between the Tibet Plateau and the ocean through the Yellow River.

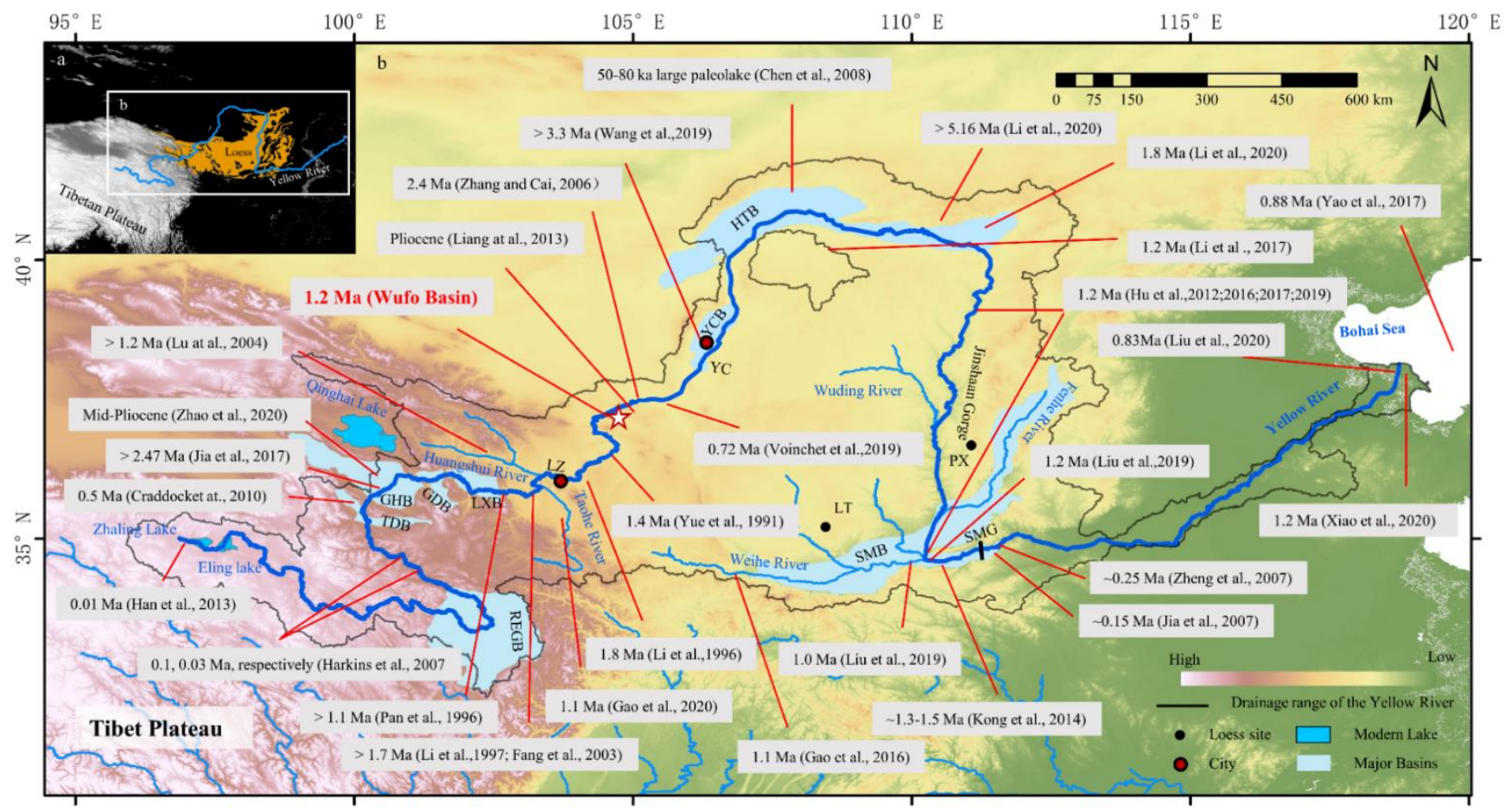

Figure 1. Study area of the Wufo Basin (red star) with the background of the Yellow River catchment. (a) Topography of the Yellow River catchment presented by Digital Elevation Model (DEM) data (SRTM V4 90 m resolution), and the extension of loess deposit in north China. (b) Overview of the Yellow River drainage and major basins along the Yellow River valley with the background of morphologic features expressed by DEM data (SRTM V4 90 m resolution data). Red lines point to the previous study areas with references marked in the grey boxes. Black lines mean the boundary of the Yellow River catchment. Dark blue polygons indicate the modern lakes and light blue polygons indicate basins that were once occupied by paleo-lakes. REGB: Ruoergai Basin; TDB: Tongde Basin; GHB: Gonghe Basin; GDB: Guide Basin; LXB: Linxia Basin; YCB: Yinchuan Basin; HTB: Hetao Basin; SMB: Sanmen Basin; SMG: Sanmen Gorge; LZ: Lanzhou City; YC: Yinchuan City; LT and PX are LingTai and PuXian loess site, respectively. 


\section{Regional Setting}

\subsection{Geographical Setting}

The Yellow River, with a watershed of 752,443 $\mathrm{km}^{2}$ and a length of $5664 \mathrm{~km}$, originates from the Bayankla Mountain on the Tibet Plateau where it shows a high gradient (Figure 2), leaves the Plateau at the Wufo Basin, runs through the Yinchuan-Hetao rift valley, flows along the Jinshan Valleys, cuts through the Sanmen Gorge [11,21,22], and finally joins the Bohai Sea, which is a marginal sea of the northwest Pacific Ocean (Figure 1).

Along its flow path, the Yellow River developed several remarkable bends: at the Ruoergai Basin [23], the Gonghe Basin [16], the Hetao Basin [13,14,24-26], and the Sanmen Basin [11]. In these basins, the Yellow River changes its flow direction sharply (nearly $180^{\circ}$ ). Such bends could be the results of former captures [23] (Figure 1). Apart from the four large basins mentioned above (Figure 1), the Yellow River crosses a series of other basins: the Tongde [10], Guide [27,28], Linxia [29], Lanzhou [30,31], Jingyuan [32,33] and Yinchuan Basins $[34,35]$. In these basins, sequences of Yellow River terraces have been developed and preserved.

The Wufo basin, at an altitude of 1290 to $1500 \mathrm{~m}$ above sea level, is the last basin that was crossed by the Yellow River before leaving the Tibet Plateau (Figure 1). At present, the average annual precipitation is less than $200 \mathrm{~mm}$. The precipitation occurs mainly in summer and is caused by the East Asian Monsoon. In winter, the climate of this region is controlled by the Asian Winter Monsoon with strong winds in cold and dry conditions. As this area is generally overlain by thick loess, geomorphic surfaces such as the fluvial terraces can be dated through paleo-magnetic stratigraphy and pedostratigraphy (loess-paleosol) correlation.

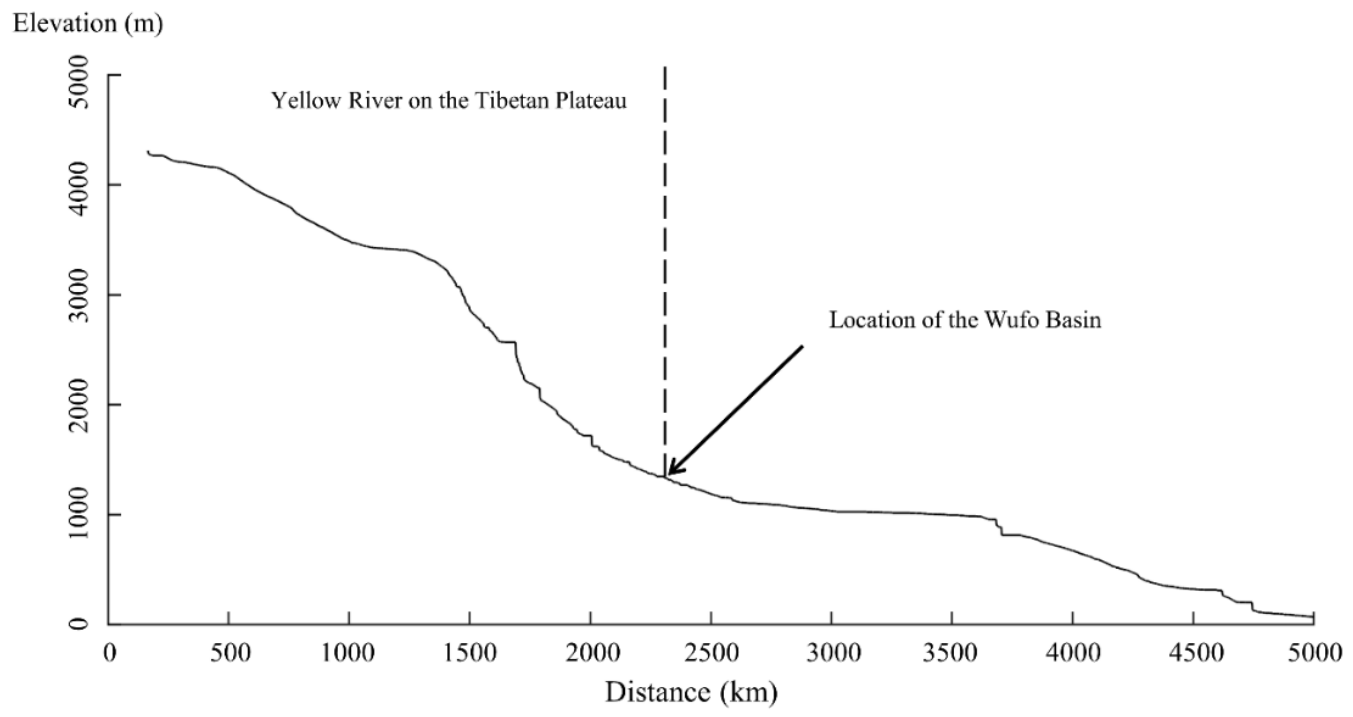

Figure 2. The longitudinal profile of the Yellow River. The black arrow shows the location of the Wufo Basin and the black dotted line shows the northeastern border of the position of the Tibet Plateau.

\subsection{Previous Researches on the Timing of the Yellow River Evolution}

The Yellow River origin has been studied for decades and the age of the modern (completed connected) Yellow River has been determined in three different views: (1) Neogene or even earlier (>3 Ma) $[13,15,16,25,34,36-40]$; (2) Early to middle Pleistocene (0.8-1.8 Ma) [10,11,17-21,24,31,41-47]; (3) Late Pleistocene ( 0.25 Ma and even younger) $[14,22,48-54]$. The argument for the first hypothesis is the Yellow River gravel layer in the Neogene strata at the Heishan [55] and Jinshaan Gorges [17,42,43], and/or the Hetao Basin [36]. Evidence for the second timeline is the age of where the Yellow River cut through the Sanmen Gorge/Jinshaan Gorge and its termination in the Bohai Sea. This hypothesis interprets the gravel layer in Neogene strata in the Jinshaan Gorge 
as deposited by local rivers, not the Yellow River [11]. This age might also be supported by the changes in the geochemical composition of the sediment in the present delta in the Bohai Sea [18-20]. In the third hypothesis, the end time of the filling of ancient, large and isolated paleo-lakes extinction is used as the age of the formation of the modern (completed and connected) Yellow River. Lakes such as the Hetao [26] and Sanmen Lakes [22,53] were suggested to develop continuously until they were cut around $250 \mathrm{ka}$ [22]. This age of $250 \mathrm{ka}$ for the formation of the modern Yellow River might be supported by the extremely high deposition rate of aeolian loess, since MIS 7 at Mangshan (near to the exit of the Sanmen Gorge). The dramatic increase in deposition of loess at this place was supposed to be due to the abrupt increase of sand/silt supply from the Yellow River which indicated that the river cut through the last gorge (Sanmen Gorge) before flowing to the Bohai Sea at that time [22]. However, this third scenario may be rejected by the occurrence of older terraces (at least 1.2 Ma) in the Sanmen Gorge [11].

The Yellow River left a series of terraces in the basins, providing the opportunity to derive the time when the modern Yellow River system formed. The ages of the terraces along the Yellow River provide the minimum age of the formation of the Yellow River. Many basins on the Tibet Plateau have been studied upstream of the Wufo Basin (Figure 1). First, an old terrace in the Lanzhou basin formed around 1.7 Ma, suggesting that the Yellow River cut through the Lanzhou Basin at least since 1.7 Ma [29]. Moreover, the recently studied Wuquan Formation (gravel sediments) at the southern side of the Lanzhou Basin was most likely deposited by the Yellow River at 3.6-2.2 Ma [41]. In the Gonghe Basin (Figures 1 and 2), located at the second large river bend of the Yellow River, a large number (maximum 24) of terraces were formed $[15,16]$. The highest of those terraces was dated at $2.47 \mathrm{Ma}$ by ESR, but also at 100-250 ka by cosmogenic analysis and luminescence analysis [54,56,57]. The oldest terrace in the Linxia Basin (Figure 1) is $1.7 \mathrm{Ma}$, similar to the Lanzhou Basin [29]. Upstream of the Tongde Basin (Figure 1) the number of Yellow River terraces is smaller while the age of the highest terrace could be much younger $[10,28,58]$. This trend of younger terrace formations in the upstream direction may support the idea of stepwise headward erosion of the Yellow River on the Tibet Plateau [10,54].

Downstream of the Wufo basin, the Yellow River crosses the Ordos block, and finally flows eastward to the Bohai Sea through the Sanmen Gorge (Figure 1). Right at the start of its course through the Ordos block, more precisely at the Zhongwei Basin (Figure 1) where preserved terraces are relatively exceptional, the second-highest terrace of the Yellow River has been dated at $0.72 \mathrm{Ma}$ by ESR [35] but this age needs further confirmation. Around 1200 to $2200 \mathrm{~km}$ further downstream, a large number of terraces is well developed and preserved; the highest one was dated around 1.2 Ma at the Jinshaan Canyon and Sanmen Gorge (Figure 1) $[17,42,43]$. The correlation of the terraces in the Wufo Basin with the terrace sequences upstream and downstream should record the history of the connection of drainages of the Yellow River in and outside the Tibet Plateau as it is located at the northeastern margin of the Tibet Plateau (Figure 1).

In addition, several gravel layers within the Neogene red sandstone upstream of the confluence with the Weihe tributary have been reported, but controversy still exists on the source of these gravel layers [13,42]. For instance, a gravel layer interpreted as the Yellow River terrace was dated at 5.16 Ma in the Hetao Basin (Figure 1) [36], and a gravel layer in the Neogene red sandstone in the Jinshaan Gorge (Figure 1) has been dated at 4.5-5.4 Ma [42] and even $8 \mathrm{Ma}$ [38]. Some researchers [42] considered that those terraces in the Neogene sandstone were formed by local rivers, as it appears from the single component of the pebble association, but other researchers found a more complicated lithology association in the gravel layer, interpreted as an indication of the Yellow River origin $[13,15]$. It suggests that the Yellow River could have formed before the Quaternary if these gravel layers are indeed of Yellow River origin [13,15]. Furthermore, provenance analysis of the Yinchuan Basin fill (Figure 1) shows that the Yellow River might have flown into this rift basin earlier than $3 \mathrm{Ma}$ [34]. Thus, the relationship of old (pre-Quaternary) gravels and high terraces downstream of the Wufo basin with a proto-Yellow River inside 
the Tibet Plateau, as recorded for instance by the gravel deposits of the Wuquan Formation at the Lanzhou basin, is still questioned [41].

\subsection{Paleo-Lakes in the Course of the Yellow River}

In the Yellow River catchment, there are many basins in which isolated paleo-lakes developed [14,22]. Some of those lakes such as the Hetao and Sanmen Lakes, may have been larger than the modern Qinghai Lake and even larger than the Baikal Lake [14]. Nowadays, most lakes are filled up by thick series of Cenozoic clastic sediments. It has been argued that those lakes were once endorheic before connecting by a Proto-Yellow River. They may have been successively captured and interconnected by the Lower Yellow River through headward erosion, leading to stepwise emptying [10]. In addition, the individual endorheic systems may have spilled over at some time and been inter-connected with a lower drainage section of the Yellow River [10,59].

The termination of those large lakes was sometimes considered as the start of the modern Yellow River [14]. Several reports have shown that the paleo Sanmen Lake (Figure 1) disappeared at $1.2 \mathrm{Ma}$, corresponding with the age of the possibly oldest terrace of the modern Yellow River in the Sanmen Gorge [45]. Similarly, a large paleolake that developed in the Hetao Basin (Figure 1) finally disappeared at 50-60 ka [14]. This event has been considered as headward erosion by the Yellow River, thus providing a strikingly young age (c. 50-60 ka) of the formation of the modern Yellow River [14], as the aforementioned third age hypothesis.

\section{Materials and Methods}

\subsection{Field Investigation and Sampling}

Yellow River terraces were recognized through field investigation, followed by mapping the approximate extension of each terrace through DEM (SRTM V4 90 m DEM) (https:/ / srtm.csi.cgiar.org/ (accessed on 6 December 2019)) and Google Earth image analysis. The primary genesis of those surfaces is that of terraces of the Yellow River as they are underlain by widely occurring fluvial beds, containing gravel from that river. The latitude, longitude, and height of each terrace and thickness of each sediment unit were measured via a differential handheld GPS receiver and a laser rangefinder, respectively. The altitude of the top of the gravel deposits has been used for correlation, taking the top of the present floodplain of the Yellow River as a reference level.

The highest terrace of the Yellow River in this basin is overlain by $\sim 43 \mathrm{~m}$ loess and alluvial sand/silt (Figures 3, 4 and 5a,b), which are documented in the NGC site (see location in Figure 3 and field photo in Figure 5a,b). We sampled those cover loess and fluvial sand/silt from top to bottom for grain size and paleomagnetic analysis. Afterwards, the fresh sediments were exposed by digging $0.5-1 \mathrm{~m}$ deep trenches.

\subsection{Laboratory Analyses}

We used pedostratigraphy of loess-paleosol sequences and magnetostratigraphy to get the accurate age of terrace T8. The sampling profile is located at the Niangoucun section (Figure 3). Terrace T8 shows $\sim 4 \mathrm{~m}$ fluvial gravel at the bottom overlain by $\sim 43 \mathrm{~m}$ loess and flood sand/silt. The bedrock of this terrace is red sandstone. 


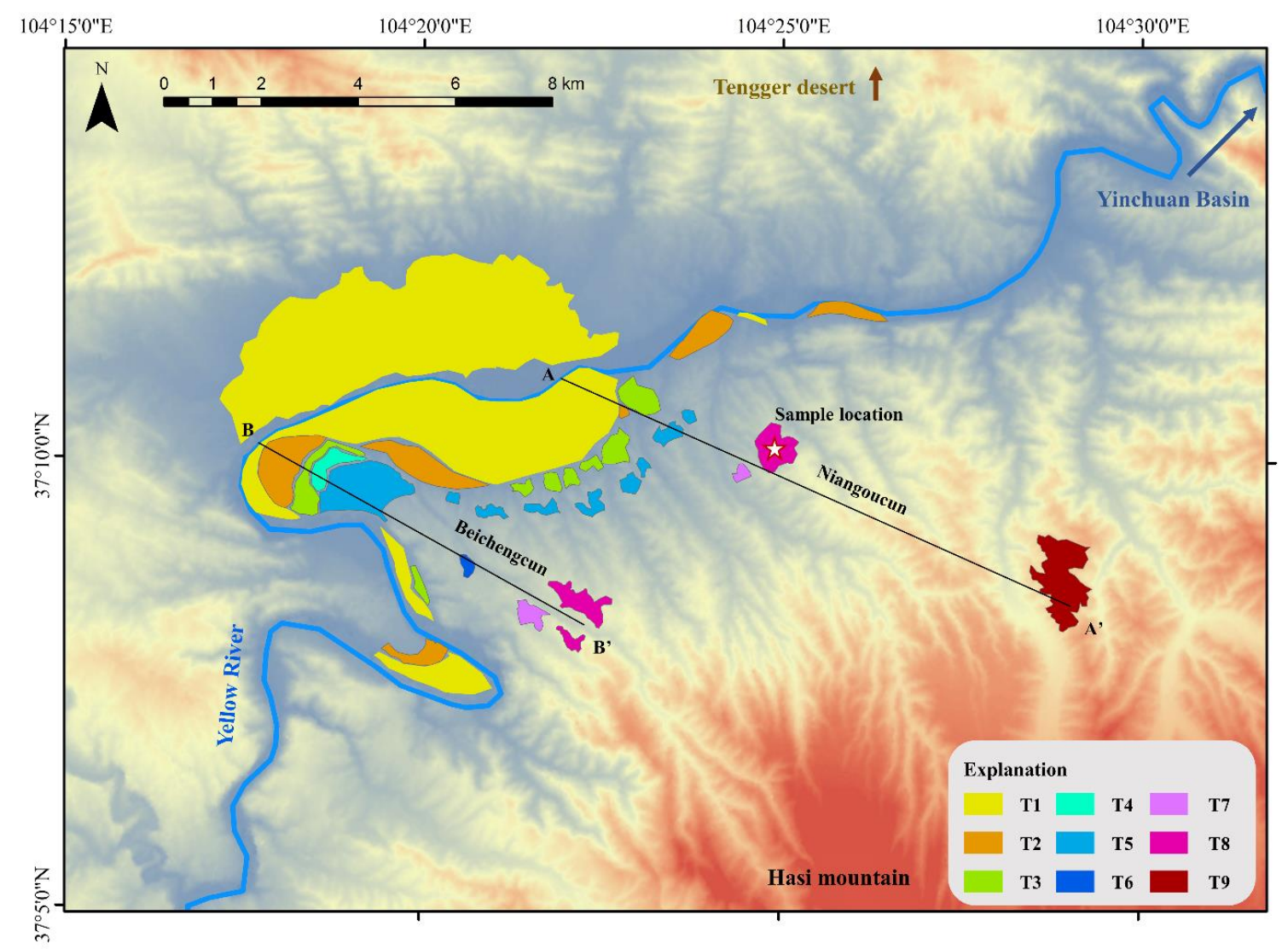

Figure 3. Topographic map (SRTM V4 $90 \mathrm{~m}$ ) with the distribution of the Yellow River terraces in the Wufo Basin (see location in Figure 1). Note: the single terrace 9 (not studied in this paper) is far away from the Yellow River with subangular to subrounded gravels (see Figure $5 \mathrm{~g}$ ), and thus it was possibly formed by local rivers. The lines (A-A' and B-B') locate the longitudinal geomorphic section in Figures 4 and 6, respectively.

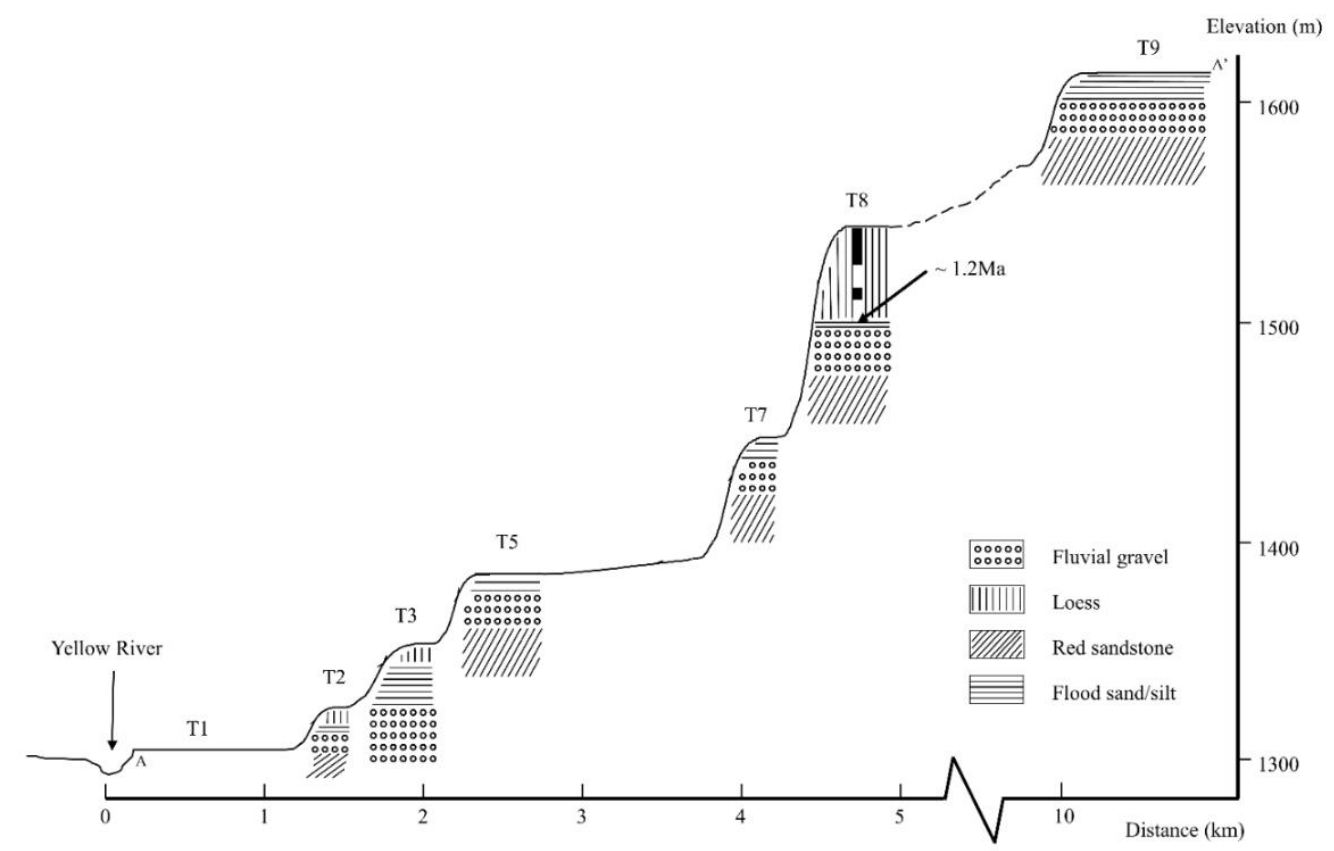

Figure 4. Schematic cross-section of the fluvial terrace staircase at the NGC site (see A-A' in Figure 3). The top of the gravel layer at terraces T2, T3, T5, T7, T8, T9 above the floodplain of the modern Yellow River are 10-20 m, 25 m, 70 m, 154 m, $190 \mathrm{~m}$, and $300 \mathrm{~m}$, respectively. 


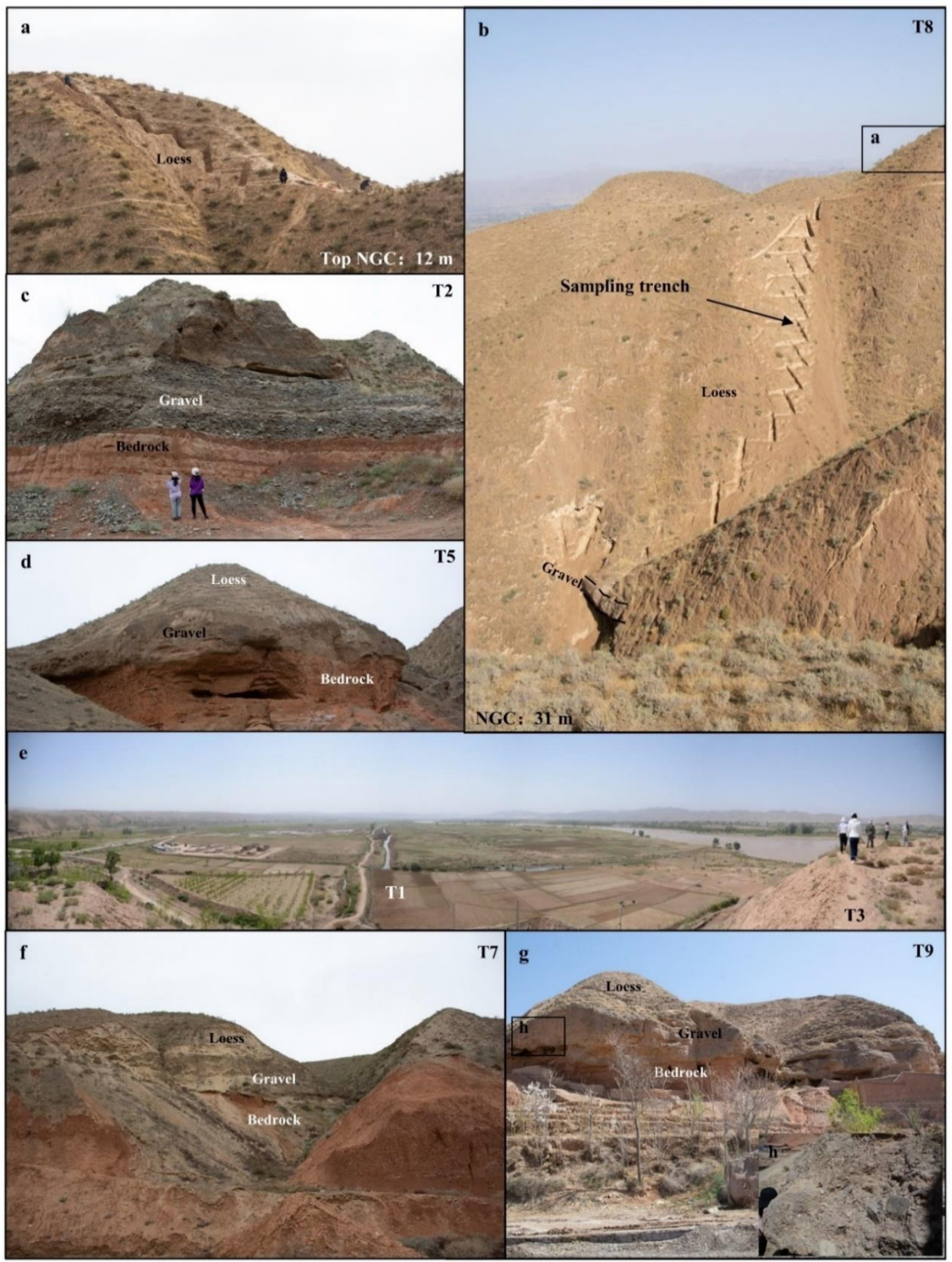

Figure 5. Field photos of each terrace at the NGC section with the sampling trenches of terrace T8. (b-d,f,g) are from terraces T8, T2, T5, T7 and T9, respectively. (e) the terraces T1 and T3. (a) the upper $12 \mathrm{~m}$ loess sediment of T8 (Top NGC, see location in (b)) and (b) the lower $31 \mathrm{~m}$ of loess and flood sand/silt sediment of T8. The staircase trenches (1-3 m high and $0.5-1 \mathrm{~m}$ deep for each one) in (a,b) are for sampling powder and paleomagnetic samples. (h) the enlarged photo of the gravel layer of terrace T9 (see location in (g)). 


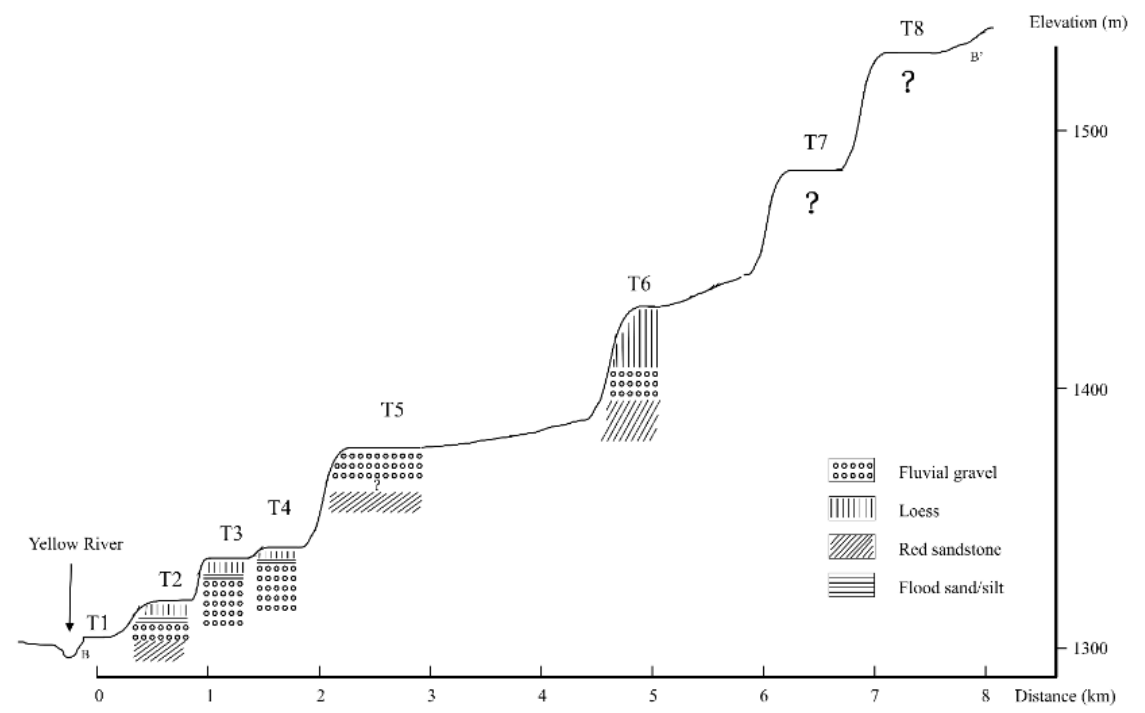

Figure 6. Schematic cross-section of the fluvial terrace staircase at the BCC site (B-B' in Figure 3). The top of the gravel layer at terraces T2, T3, T4, T5, T6 above the floodplain of the modern Yellow River is 10-20 m, $30 \mathrm{~m}, 34 \mathrm{~m}, 65 \mathrm{~m}, 115 \mathrm{~m}$, respectively. Terraces T7 and T8 at BCC sites were hard to reach and their distributions were deduced through DEM and Google earth images.

\subsubsection{Magnetostratigraphy}

Ninety-eight paleomagnetic samples from the covering loess and the fluvial silty sand of T8 were taken with an interval of $1-2 \mathrm{~m}$ in the upper $18 \mathrm{~m}$ and $10-50 \mathrm{~cm}$ in the lower $25 \mathrm{~m}$ of the section for thermal demagnetization. The demagnetization was measured with a 2G Enterprise 755 Cryogenic Superconducting Magnetometer. All specimens were subjected to thermal demagnetization with steps at room temperature, $150{ }^{\circ} \mathrm{C}, 200^{\circ} \mathrm{C}$, $250{ }^{\circ} \mathrm{C}, 300{ }^{\circ} \mathrm{C}, 350{ }^{\circ} \mathrm{C}, 400{ }^{\circ} \mathrm{C}, 450{ }^{\circ} \mathrm{C}, 500{ }^{\circ} \mathrm{C}, 525^{\circ} \mathrm{C}, 550{ }^{\circ} \mathrm{C}, 580{ }^{\circ} \mathrm{C}, 600{ }^{\circ} \mathrm{C}, 625^{\circ} \mathrm{C}$, $650^{\circ} \mathrm{C}, 680^{\circ} \mathrm{C}$ using a TD-40 Thermal demagnetizer at the School of Earth Sciences and Engineering, Nanjing University. Both the demagnetizer and the magnetometer were installed in a shielded room with a residual field of less than $200 \mathrm{nT}$. The demagnetization results were evaluated using orthogonal projection diagrams [64]. After removing the lowtemperature viscous component, the characteristic remnant magnetization (ChRM) was successfully isolated (Supplementary Materials, Figure S1). All the data of paleomagnetic samples were analyzed via the software, Pufillin-1.4.1 [65], and at least 4 (but typically 5-8) consecutive demagnetization steps above $250{ }^{\circ} \mathrm{C}$ were used to calculate the $\mathrm{ChRM}$ direction, with a maximum angular deviation (MAD) of less than $15^{\circ}$ for the respective line fit (Supplementary Materials, Figure S1).

\subsubsection{Grain-Size Measurements}

A total of $\sim 430$ sediment samples were collected at an interval of $10 \mathrm{~cm}$ for grain-size measurement to distinguish loess and soil layers [9], which is used for the correlation of pedostratigraphy of the studied section with well-dated loess-paleosol sequences. All these samples were measured through the methods described by Konert and Vandenberghe [60-62] at the School of Geography and Ocean Science, Nanjing University. The laboratory procedures were in general as follows: (1) About $0.3-0.5 \mathrm{~g}$ of bulk sediment was oxidized with $10 \%$ hydrogen peroxide $\left(\mathrm{H}_{2} \mathrm{O}_{2}\right)$ to remove organic matter; (2) $10 \%$ hydrochloric acid $(\mathrm{HCl})$ was added to remove carbonate; (3) breakers were filled with deionized water and left overnight; (4) after removing the supernatant, $10 \mathrm{~mL} 0.05 \mathrm{~mol} / \mathrm{L}$ sodium hexametaphosphate $\left(\left(\mathrm{NaPO}_{3}\right)_{6}\right)$ was added as a dispersing agent prior to $10 \mathrm{~min}$ of ultrasonic dispersion; and then, all samples were measured using a Malvern master-size laser particle analyzer. The grain-size distribution shows 100 size classes, ranging from 0.02 to $2000 \mu \mathrm{m}$. Finally, all the original grain-size data were analyzed via the software of Analysis v1.1.2 in MATLAB R2019b [63] for further analysis. 


\section{Results}

\subsection{The Distribution of the Yellow River Terraces in the Wufo Basin}

Two terrace series were mapped at the Niangoucun section (NGC) and Beichengcun section (BCC), respectively (Figure 3). Each terrace in the Wufo Basin has similar sedimentary records: red sandstone as the bedrock, fluvial gravels of various thickness and capped by flood sand/silt, and ultimately the covering aeolian loess (Figures 4 and 6). The boundary between flood sediments and loess is not always clear, and terrace T1 is not exposed in the study area.

\subsubsection{Niangoucun Section (NGC)}

In this section, we identified 7 Yellow River terraces (Figure 4). Terrace T1 is a fill terrace at 2-8 $\mathrm{m}$ above the modern Yellow River. Although the base of sediment sequence below this morphological flat surface (T1) was buried by the present floodplain, it was a terrace rather than an active alluvial plain, due to its alluvial cover in reality being abandoned and replaced by the present-day alluvial sequence at a much lower altitude (Figures 4 and 5e). This lowest terrace also developed upstream along the Yellow River, where the top of the bedload gravel layer of this terrace was exposed above the present channel in some places [66].

Other terraces are strath terraces with red Neogene sandstone/conglomerate as the bedrock. At each terrace level, a fluvial gravel layer occurs, with the top of the gravel layers located at 10-20 m, $28 \mathrm{~m}, 70 \mathrm{~m}, 154 \mathrm{~m}, 190 \mathrm{~m}$, and $300 \mathrm{~m}$ above the floodplain of the Yellow River, respectively. The thickness of the loess and alluvium overlying the fluvial gravel unit is shown in Table 1.

Table 1. Terrace level, the height of the top of the fluvial gravel above the floodplain of the modern Yellow River, the thickness of the gravel unit, and the thickness of the flood sand/silt and loess units. ("?" means the thickness is uncertain due to incomplete exposure).

\begin{tabular}{|c|c|c|c|c|}
\hline Location & Terrace Level & $\begin{array}{l}\text { Gravel Layer } \\
\text { Thickness }\end{array}$ & $\begin{array}{c}\text { Thickness of Loess and Flood } \\
\text { Sand/Silt }(m) *\end{array}$ & $\begin{array}{c}\text { Height of the Top of Gravel above } \\
\text { the Floodplain of the Modern } \\
\text { Yellow River (m) }\end{array}$ \\
\hline \multirow[t]{7}{*}{ NGC } & $\mathrm{T} 1$ & Not exposed & - & - \\
\hline & $\mathrm{T} 2$ & 8 & 8 & $10-20$ \\
\hline & T3 & $>11$ & 17 & 28 \\
\hline & $\mathrm{T} 5$ & 5.5 & 4.5 & 70 \\
\hline & $\mathrm{T} 7$ & 4 & 9 & 154 \\
\hline & $\mathrm{T} 8$ & 4 & 43 & 190 \\
\hline & T9 ** & 4 & 10 & 300 \\
\hline \multirow[t]{6}{*}{ BCC } & $\mathrm{T} 1$ & Not exposed & - & - \\
\hline & $\mathrm{T} 2$ & 3-6 & $1-2$ & $10-20$ \\
\hline & T3 & $>3 ?$ & 4 & 30 \\
\hline & $\mathrm{T} 4$ & 6.5 & 6 & 34 \\
\hline & $\mathrm{T} 5$ & $>11 ?$ & $?$ & 65 \\
\hline & T6 & 4 & 17 & 115 \\
\hline
\end{tabular}

Note: * The boundary of floodloam (silt) and covering loess is hard to distinguish in the field, because the transition from fluvial sand/silt to loess is gradual under the condition of continuous aeolian loess inputting. ${ }^{* *}$ Terrace T9 may be developed by a local gully, so we did not analyze this terrace in this study.

\subsubsection{Beichengcun Section (BCC)}

We identified 6 Yellow River terraces through field survey and DEM/Google Earth image analysis at the BCC site. All terraces are strath terraces except T1. The height of the top gravel layer of each terrace is $10-20 \mathrm{~m}, 30 \mathrm{~m}, 34 \mathrm{~m}, 65 \mathrm{~m}$, and $115 \mathrm{~m}$ above the floodplain of the modern Yellow River, respectively (Figures 3, 6 and 7; Table 1). The thickness of each sedimentary unit covering the terraces is shown in Table 1. 


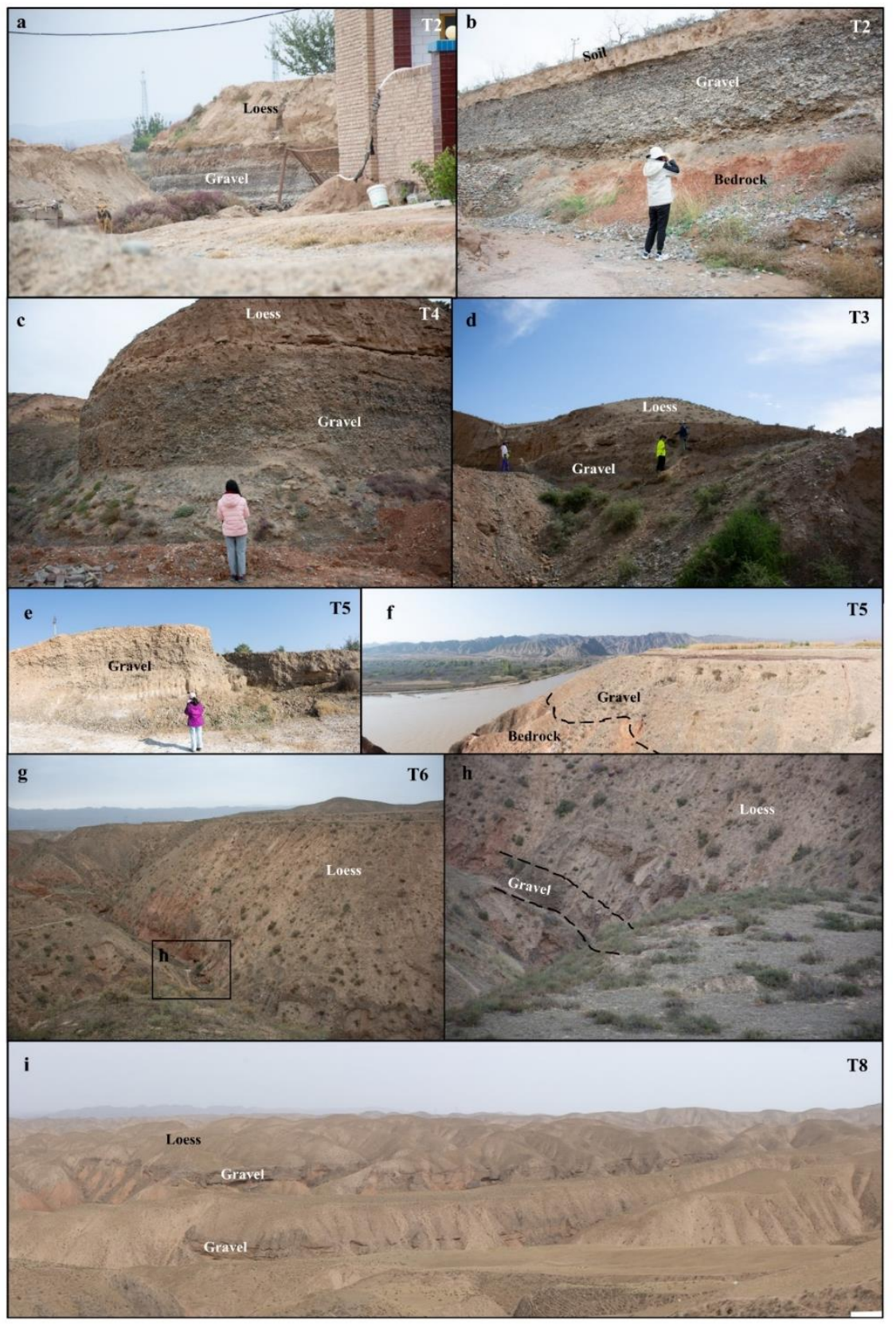

Figure 7. Field photos of each terrace at the BCC section. (a-g,i) show terraces T2, T4, T3, T5, T6, and $\mathrm{T} 8$, respectively. $(\mathbf{a}, \mathbf{b})$ show that the same terrace (T2) at different sites has a different thickness of flood sand/silt and loess. (h) Shows that the top of T5 may be eroded.

The height of the top of the gravel layer of the lower terraces T2, T3 and T5 above the modern Yellow River are equivalent in both sections. In summary, at least 8 Yellow River terraces were identified in the Wufo Basin with the top of the gravel layer above the floodplain of the modern Yellow River at 10-20 m, 30 m, 34 m, 70 m, 115 m, 150 m, and $190 \mathrm{~m}$, respectively (Figures 3 and 8 ). 


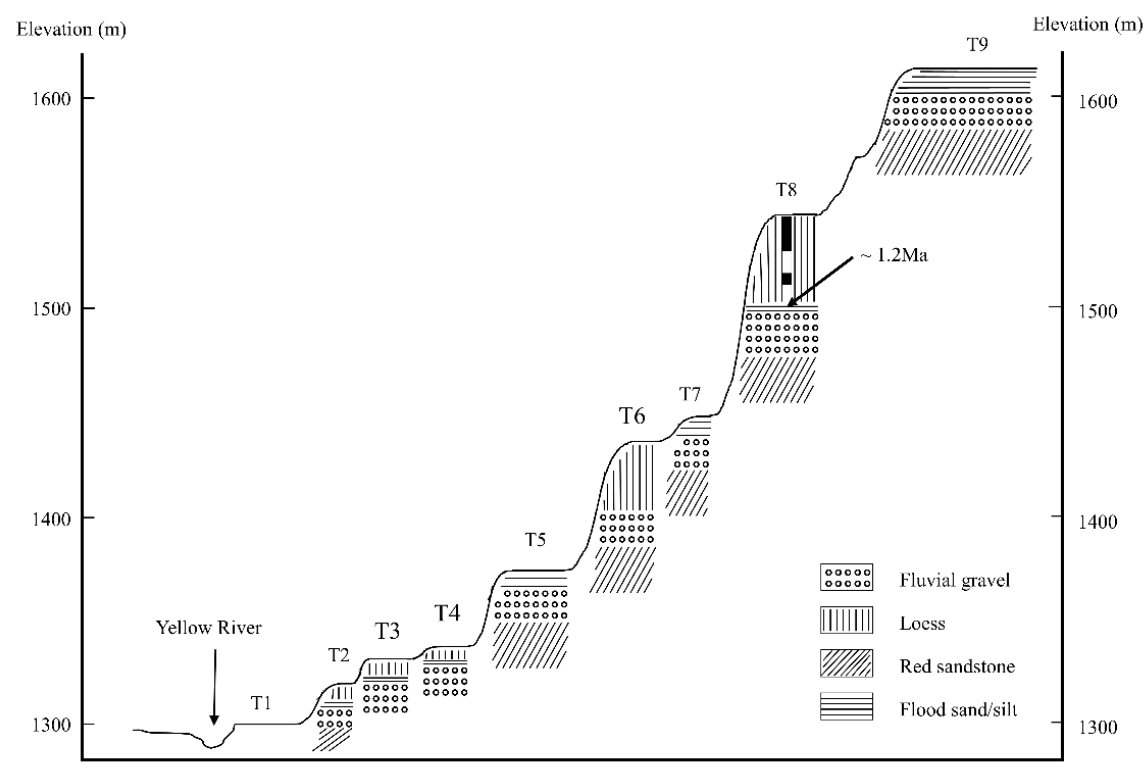

Figure 8. The composite Yellow River terrace sequence in the Wufo Basin.

\subsection{Description of the Sediments and the Age of Terrace T8}

\subsubsection{Lithologic Characteristics}

Terrace T8 contains a $4 \mathrm{~m}$ thick gravel layer and a $\sim 43 \mathrm{~m}$ thick fluvial sand/silt and loess layer. The bedrock of this terrace is red sandstone (Figures 5 and 9). The upper $36 \mathrm{~m}$ of loess is brownish (10YR 6/4) and quite homogeneous. The lower $7 \mathrm{~m}$ sediment, consisting of loess and fluvial sand/silt, is more reddish (from 10YR 6/4 to 10YR 5/6,5/8,7/4) with a caliche nodule layer at $35 \mathrm{~m}$ and a layer of ferrimagnetic cutans at around $40 \mathrm{~m}$. No erosion interface has been found in the section (Figure 9).

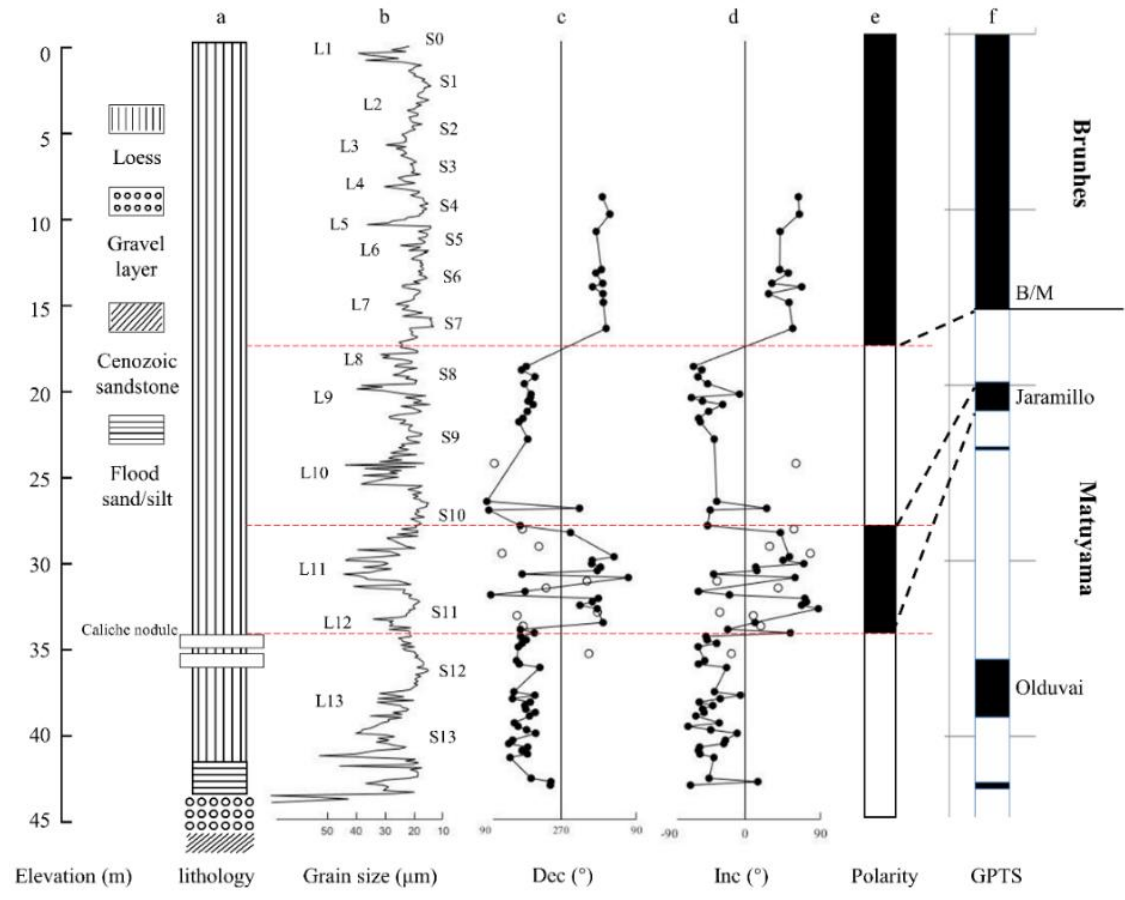

Figure 9. Lithology (a), median grain-size record (b), magnetostratigraphy (c,d) and the correlation of the polarity (e) between the sediment sequence covering the terrace (T8) at the NGC site (see field photo in Figure 5) and the GPTS (f): geomagnetic polarity time scale [67]. 
The frequency distribution of the grain size from the loess-paleosol series shows a unimodal curve with a coarse tail, while the loess is coarser than the paleosols (Figure 10). The grain size from the sand directly on top of the gravel shows a bimodal distribution with the modal size of the coarse component around $600-800 \mu \mathrm{m}$ and the modal size of the fine component around 10-30 $\mu \mathrm{m}$ (Figure 10).

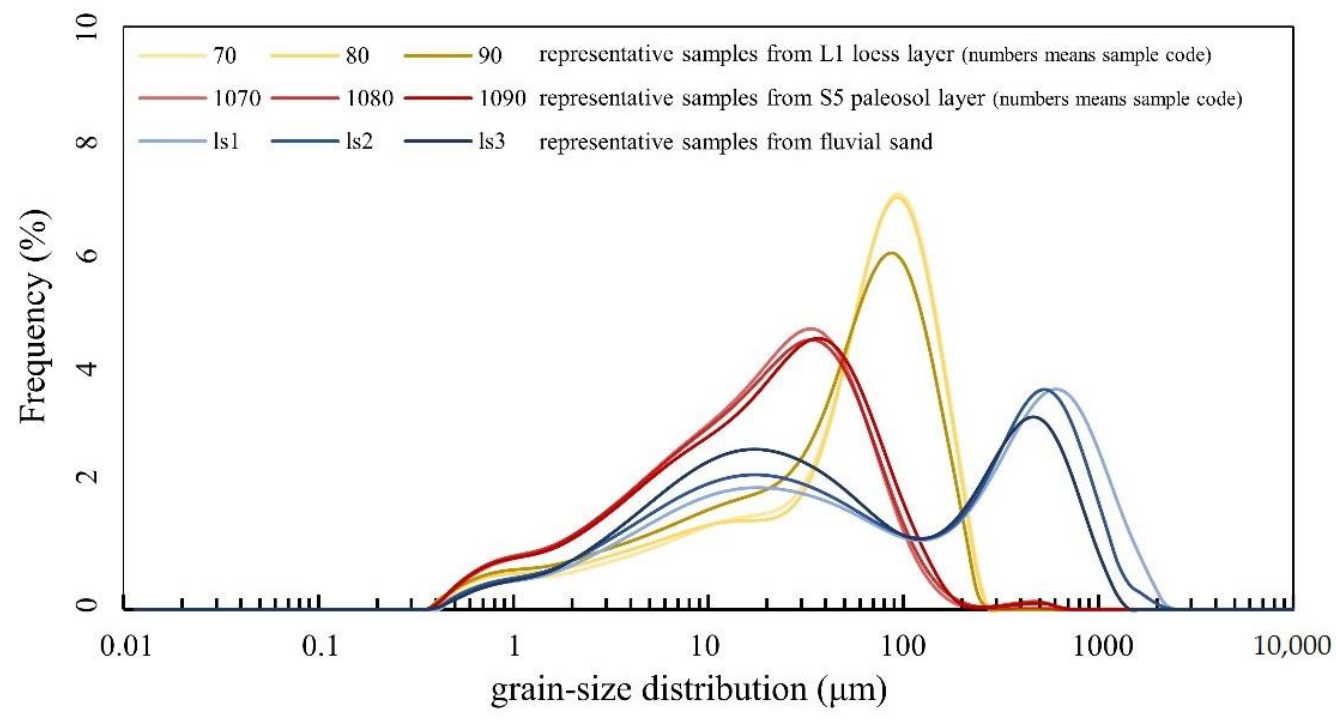

Figure 10. The grain-size distribution of sediments at the NGC site. The brown, red and blue lines represent the grain-size distribution of typical loess (L1), paleosol (S5) and fluvial sand, respectively. Samples coded in numbers represent the depth $(\mathrm{cm})$ of loess overlaying the terrace T8, ls1-ls3 are fluvial sand powder samples from the sand on top of the gravel of terrace $\mathrm{T} 8$.

\subsubsection{Loess-Paleosol Sequence}

The loess-paleosol sequence is the archive of glacial-interglacial cycles on the Chinese Loess Plateau, and each loess and soil layer was dated by astronomical tuning [68]. This general time series of the loess-paleosol sequence is widely used for dating river terraces that were covered by loess in this area, based on the assumption that the terraces were immediately capped by loess after its formation [69-71].

The variations of the Median Grain Diameter (MGD) from the top to the base of the loess sequence covering T8 shows a similar trend as that in the Lingtai/Puxian section (typical loess-paleosol series in the central part of the Chinese Loess Plateau) and Lanzhou sites (Supplementary Materials, Figure S2). This indicates that the aeolian sequence covering the terrace was composed of 13 loess-paleosol units marked as $\mathrm{Li}$ for loess and $\mathrm{Si}$ for soil layers ( $i=1,2,3 \ldots$, counting from top to bottom) (Figure 9). According to the correlation of loess-paleosol cycles with glacial-interglacial cycles [68], 13 climatic cycles after the terrace (T8) formation were distinguished, and loess deposits on the terrace were deposited around 1.2 Ma as the initial age of the 13th paleosol [68]. In addition, the average grain size from the loess sequence covering T8 was coarser than loess from the Lingtai [68] and Lanzhou sections [72] (Supplementary Materials, Figure S2). This means that the study area could have been closer to the dust source or have experienced a stronger wind $[68,73]$. Moreover, a small peak $(\sim 400 \mu \mathrm{m})$ in the grain-size distribution curve may indicate a local source of floodplain sand reworked by aeolian action (Supplementary Materials, Figures S2 and S3) $[5,66,74-76]$.

\subsubsection{Paleomagnetic Stratigraphy}

Finally, 81 samples provided reliable data to establish a magnetic stratigraphic polarity and a total of two normal polarities and two reversed polarities are present (Figure 9) (25 samples with normal polarity, 46 samples with reversed polarity, and the inclination 
and declination of other 10 samples show different polarities). The mean normal inclination is $47.8^{\circ}$ and that of reversed signals is $-42.3^{\circ}$ (Supplementary Materials, Figure S4). A difference of $5^{\circ}$ is found between the reversed directions throughout the reversed test, supporting the reliability of the paleomagnetic stratigraphy [64].

Loess deposition covering T8 is continuous as no major erosion interface has been found, thus the upper normal polarity should correspond to the Brunhes period, and the two reversed polarities and another normal polarity belong to the Matuyama period [67]. This result is consistent with loess-paleosol sequences, and similar to previous reports $[68,77,78]$ that the $\mathrm{B} / \mathrm{M}$ boundary is located in the upper part of L8 while the upper and lower boundaries of the Jaramillo event are located in S10 and L12, respectively (Figure 9). Investigations show that aeolian sediments were deposited continuously in this region during the Quaternary [68], and the changes of grain size from fluvial sand to loess are gradual (Figure 9), suggesting the absence of distinct hiatus between fluvial sand and aeolian loess on the terrace (T8). Thus, it is reasonable to assume that as soon as terraces were formed after floodplain abandonment, dust started to accumulate on the dry terrace surfaces [31]. Therefore, the terrace (T8) dates from c. 1.2 Ma when the aeolian sedimentation had started on this terrace surface.

\section{Discussion}

\subsection{Flow-Through Paleolakes Rather Than Endorheic Lakes in the Course of the Yellow River}

It may be seriously questioned whether the time of paleolake disappearance could be used as an indication of the start of the modern Yellow River, apart from the obvious occurrence of older terraces of the Yellow River origin. Nowadays there are many lakes in the source area of the Yellow River, such as the Zaling and Eling Lakes, which are not endorheic but are crossed by rivers (Figure 1). Additionally, large lakes, such as the Dongting and Poyang Lakes in southern China, coexist with the Yangtze River as so-called barrier lakes. During the rainy season, rivers feed the lakes, while in the dry season, lakes feed the river [79]. Salt lakes prove a closed basin environment while fresh-water lakes indicate fluvial flushing in this arid condition. In the semi-arid area of the upper Yellow River, closed basins are generally salt lakes, such as the Qinghai and Luyang Lake (Figure 1), but the exoreic lakes are fresh-water lakes, such as the Zaling and Eling Lakes at the headwaters of Yellow River (Figure 1). Therefore, we derived that paleo-lakes and the Yellow River could co-exist in the catchment. However, climatic conditions may also have interfered. During the Quaternary, northwestern China became dryer [9,80-82] while the climate fluctuated [68,83-87]. Thus, it is not surprising that large paleo-lakes have existed in northwestern China during the wet phases in the Pleistocene $[26,88]$.

Until now, considerable amounts of salt deposits have not been detected in paleo-lakes in the Yellow River valley (such as the Hetao and Sanmen Basins). Sediments in those basins (except the Yinchuan basin), which in the area of the Yellow River catchment show a freshwater environment since $\sim 40 \mathrm{Ma}$, and not a salt lake (e.g., no brine deposit) $[40,89,90]$. This indicates exorheic drainage connected those paleo-lakes. In other words, these large paleolakes were barrier-like lakes of the Yellow River rather than endorheic lakes [40,90].

\subsection{When Did the Yellow River Extend Headward into the Tibet Plateau and Debouched into the Bohai Sea?}

Previous results show that the Upper Yellow River (upstream of the Lanzhou Basin) formed earlier than 1.7 Ma [29], and the Middle-Lower Yellow River (downstream of Lanzhou) flowed to the Bohai Sea at least since 1.2 Ma [17,42]. Our new results add reliable data of the Yellow River entrenchment into the Tibet Plateau.

Terraces have been dated at 1.1 to 1.2 Ma in the Xunhua [91], Linxia [29], Lanzhou [31], Wufo (this study), and possibly Gonghe Basins [16] on the Tibet Plateau. This is similar in the Hetao Basin [13,25], Jinshaan Canyon [17,42,43], Sanmen Basin, and Sanmen Gorge [11] at downstream and marginal positions with regard to the Tibet Plateau. This demonstrates that a connection existed between sections of the Yellow River in the Hetao Basin, Jinshaan 
Canyon and Sanmen Gorge and parts of the Yellow River on the Tibet Plateau through the Wufo basin at least since 1.2 Ma. Recently, provenance analysis of the Yellow River delta at the Bohai Sea shows that the material composition significantly changed at $\mathrm{c}$. $1.2 \mathrm{Ma},>0.88 \mathrm{Ma}$ [18], or $>0.83 \mathrm{Ma}$ [20], most likely caused by the Yellow River extension to the Tibet Plateau [19]. Indirect supporting evidence is provided by the oldest terraces of the Taohe River and Weihe River (two large tributaries of the Yellow River) dated at c. 1.2 Ma [92,93], and the possible changed flow direction of the Huangshui River to the east, joining the Yellow River at c. 1.4 Ma (Figure 1) [69-71]. Recently, it has been shown that the Yellow River may finally have crossed the Hetao Basin at 1.2 Ma [74]. It should be mentioned that terraces, especially old ones, may have been destroyed by later erosion, for instance in gorges, such as the Sanmen Gorge (Figure 1). The combination of these data with our new terrace data in the Wufo basin demonstrates that the middle Yellow River extended to the Tibet Plateau at least since 1.2 Ma.

In addition, some river terraces (or depositions) formed much earlier than 1.2 Ma; their gravel and heavy-mineral associations point to an Upper Yellow River source (e.g., the highest river terraces in the Gonghe Basin $[15,16]$ and terraces which occur in the Neogene red sandstone of the Hetao Basin [13] and the Jinshaan canyon [17,42,43], and river deposition in the Lanzhou Basin (Wuquan Formation) [41] and the Yinchuan Basin [34]). Hu et al. $[11,17,42]$ dated the first connection between the Sanmen Basin and the Bohai Sea at least between the highest terrace along the Sanmen Gorge (1.2 Ma) and the formation of a planation level $(3.6 \mathrm{Ma})$ [46]. Although it is debated whether gravel sediments of these much older than 1.2 Ma terraces were transported and deposited by the Yellow River [13], the speculation of old age (older than 3.6 Ma) of the Yellow River would require the identification of fluvial sediments with the Tibet Plateau signature of such age. In addition, the proto-Yellow River might flow to the Sanmen Basin through the trunk stream of Weihe River, one of the present tributaries (Figure 1) [40], and then it migrated to the north and finally formed the third great bend of the Yellow River at Hetao Basin due to the tectonic activity [40].

River terraces upstream of the Tongde Basin (Figure 1) are very young (younger than $100 \mathrm{ka}$, and even $10 \mathrm{ka}$ ), which may indicate an imminent piracy event, namely the capture of the most upstream endorheic system on the Tibet Plateau by the Yellow River [23]. This supports the idea that the transition of endorheic to exorheic drainage may have occurred stepwise on the Tibet Plateau [10].

We concluded that the Yellow River extended to the northeastern Tibet Plateau via headward erosion at least since 1.2 Ma. Large paleo-lakes (such as the Hetao [14] and Sanmen Lakes $[11,21,22,51])$ acted as barrier lakes that coexisted with the Yellow River. Sediments in those basins may have recorded the history of the upstream Proto-Yellow River.

\section{Conclusions}

In the Wufo basin, at least eight terraces of the Yellow River formed at the boundary between the Tibet Plateau and Ordos block. The magneto-stratigraphy and loess-paleosol sequences on top of the oldest Yellow River terrace prove that the age of the terrace is c. 1.2 Ma. Combining previous results on the terraces of the Yellow River and the delta suggests that the Yellow River extended into the Tibet Plateau at least since 1.2 Ma. At the same time, large paleo-lakes might have developed locally in the basins of the Yellow River while acting as barrier lakes. Further research on the origin of old gravel sediments and terraces and paleo-lakes along the Yellow River could determine the more precise timing of the breakthrough of the Sanmen Gorge by the modern Yellow River drainage and the extension of the Yellow River into the Tibet Plateau.

Supplementary Materials: The following are available online at https: / www.mdpi.com/article / 10.3390/quat4020014/s1, Figure S1: Results of the thermal demagnetization of the representative samples. Figure S2: Comparison of the median grain-size record in the Wufo Basin (this study), Lanzhou site and the central Chinese Loess Plateau (Lingtai and Puxian). Figure S3: Grain-size 
distribution of the floodplain deposit and loess overlaying terrace T8. Figure S4: Histogram of the magnetic inclinations of terrace T8.

Author Contributions: Conceptualization, X.W.; methodology, Z.L., X.W. and J.V.; software, Z.L.; validation, Z.L., X.W., J.V. and H.L.; formal analysis, Z.L. and X.W.; investigation, Z.L., X.W. and J.V.; resources, Z.L., X.W. and H.L.; data curation, Z.L. and X.W.; writing-original draft preparation, Z.L. and X.W.; writing-review and editing, Z.L., X.W., J.V. and H.L.; visualization, Z.L. and H.L.; supervision, J.V. and H.L.; project administration, X.W.; funding acquisition, X.W. and H.L. All authors have read and agreed to the published version of the manuscript.

Funding: This research was supported by the National Natural Science Foundation of China (41971005), the Second Tibet Plateau Scientific Expedition Program (STEP) (2019QZKK0205), and the National Key Research and Development Program (2016YFA0600500).

Acknowledgments: We thank David Bridgland's encouragement for this work. We thank Xuzhi Hu and BinYang for their help in laboratory analysis, and Yang Yu, Dongxu Cai, Xiaolu Dong, and Qi Yu for their help in the fieldwork. Special thanks to Xun Yang for constructive suggestions in mapping. The authors thank two anonymous reviewers for their constructive suggestions.

Conflicts of Interest: The authors declare no conflict of interest.

\section{References}

1. Davis, W.M. The stream contest along the Blue Ridge. Geol. Soc. Phil. Bull. 1903, 3, 213-244.

2. Holbrook, J.; Schumm, S.A. Geomorphic and sedimentary response of rivers to tectonic deformation: A brief review and critique of a tool for recognizing subtle epeirogenic deformation in modern and ancient settings. Tectonophysics 1999, 305, $287-306$. [CrossRef]

3. Wang, P.; Tian, J.; Huang, E.; Ma, W. Earth System and Evolution; China Science Publishing: Beijing, China, 2018; ISBN 9787030576040. (In Chinese)

4. Burbank, D.W. Causes of recent Himalayan uplift deduced from deposited patterns in the Ganges basin. Nature 1992, 357, 680-683. [CrossRef]

5. Yang, X.; Wang, X.; Van Balen, R.T.; Prins, M.A.; Wang, S.; van Buuren, U.; Lu, H. Fluvial terrace formation and its impacts on early human settlement in the Hanzhong basin, Qinling Mountains, central China. Glob. Planet. Chang. 2019, 178, 1-14. [CrossRef]

6. Hoorn, C.; Wesselingh, F.P.; ter Steege, H.; Bermudez, M.A.; Mora, A.; Sevink, J.; Sanmartin, I.; Sanchez-Meseguer, A.; Anderson, C.L.; Figueiredo, J.P.; et al. Amazonia through time: Andean uplift, climate change, landscape evolution, and biodiversity. Science 2010, 330, 927-931. [CrossRef] [PubMed]

7. Molnar, P.; Tapponnier, P. Cenozoic Tectonics of Asia: Effects of a Continental Collision. Science 1975, 189, 419. [CrossRef] [PubMed]

8. Tapponnier, P.; Zhiqin, X.; Roger, F.; Meyer, B.; Arnaud, N.; Wittlinger, G.; Jingsui, Y. Oblique Stepwise Rise and Growth of the Tibet Plateau. Science 2001, 294, 1671-1677. [CrossRef]

9. Guo, Z. Loess Plateau attests to the onsets of monsoon and deserts. Sci. Sin. Terrae 2017, 47, 421-437. (In Chinese)

10. Craddock, W.H.; Kirby, E.; Harkins, N.W.; Zhang, H.; Shi, X.; Liu, J. Rapid fluvial incision along the Yellow River during headward basin integration. Nat. Geosci. 2010, 3, 209-213. [CrossRef]

11. Hu, Z.; Li, M.; Dong, Z.; Guo, L.; Bridgland, D.; Pan, B.; Li, X.; Liu, X. Fluvial entrenchment and integration of the Sanmen Gorge, the Lower Yellow River. Glob. Planet. Chang. 2019, 178, 129-138. [CrossRef]

12. Bridgland, D.R.; Westaway, R.; Hu, Z. Basin inversion: A worldwide Late Cenozoic phenomenon. Glob. Planet. Chang. 2020, 193, 103260. [CrossRef]

13. Zhao, X.; Jia, L.; Hu, D. Discoveries of Fluvial Terraces and Neogene Gravels in the Hetao Area, Inner Mongolia: Implications for the Development of the Yellow river, Antiquity of Chinese Rivers, and Coexistence Theory of Rivers and Lakes. Acta Geol. Sin-Engl. 2018, 92, 845-886. (In Chinese)

14. Chen, F.; Fan, Y.; Chun, X.; Madsen, D.B.; Oviatt, C.G.; Zhao, H.; Yang, L.; Sun, Y. A Preliminary Study on the "Jilantai-Hetao" Ancient Large Lake in the Late Quaternary. Chin. Sci. Bull. 2008, 53, 1207-1219. (In Chinese)

15. Zhao, X.; Jia, L.; Hu, D.; Li, W.; Lin, X. The Discovery of the Pliocene Yellow River Paleochannel between Gonghe and Guide Basins, Qinghai Province: Concurrent Discussion on the Formation of the Longyang Gorge and the "Gonghe Movement". Acta Geosci. Sin. 2020, 41, 453. (In Chinese)

16. Jia, L.; Hu, D.; Wu, H.; Zhao, X.; Chang, P.; You, B.; Zhang, M.; Wang, C.; Ye, M.; Wu, Z.; et al. Yellow River terrace sequences of the Gonghe-Guide section in the northeastern Qinghai-Tibet: Implications for plateau uplift. Geomorphology 2017, 295, 323-336. [CrossRef]

17. Hu, Z.; Pan, B.; Bridgland, D.; Vandenberghe, J.; Guo, L.; Fan, Y.; Westaway, R. The linking of the upper-middle and lower reaches of the Yellow River as a result of fluvial entrenchment. Quat. Sci. Rev. 2017, 166, 324-338. [CrossRef]

18. Yao, Z.; Shi, X.; Qiao, S.; Liu, Q.; Kandasamy, S.; Liu, J.; Liu, Y.; Liu, J.; Fang, X.; Gao, J.; et al. Persistent effects of the Yellow River on the Chinese marginal seas began at least $\sim 880 \mathrm{ka}$ ago. Sci. Rep. 2017, 7, 2827. [CrossRef] 
19. Xiao, G.; Sun, Y.; Yang, J.; Yin, Q.; Dupont-Nivet, G.; Licht, A.; Kehew, A.E.; Hu, Y.; Geng, J.; Dai, G.; et al. Early Pleistocene integration of the Yellow River I: Detrital-zircon evidence from the North China Plain. Paleogeogr. Paleoclimatol. Paleoecol. 2020, 546, 109691. [CrossRef]

20. Liu, J.; Zhang, J.; Miao, X.; Xu, S.; Wang, H. Mineralogy of the core YRD-1101 of the Yellow River Delta: Implications for sediment origin and environmental evolution during the last $1.9 \mathrm{Myr}$. Quat. Int. 2020, 537, 79-87. [CrossRef]

21. Kong, P.; Jia, J.; Zheng, Y. Time constraints for the Yellow River traversing the Sanmen Gorge. Geochem. Geophys. Geosyst. 2014, 15, 395-407. [CrossRef]

22. Zheng, H.; Huang, X.; Ji, J.; Liu, R.; Zeng, Q.; Jiang, F. Ultra-high rates of loess sedimentation at Zhengzhou since Stage 7: Implication for the Yellow River erosion of the Sanmen Gorge. Geomorphology 2007, 85, 131-142. [CrossRef]

23. Wang, Y.; Wang, S.; Xue, B.; Ji, L.; Wu, J.; Xia, W.; Pan, H.; Zhang, P.; Chen, F. The Sedimentological Basis of the Age of the Ancient Lake Ruoergai by the Yellow River. Chin. Sci. Bull. 1995, 40, 723-725. (In Chinese)

24. Li, X.; Zhang, H.; Wang, Y.; Zhao, X.; Ma, Z.; Liu, K.; Ma, Y. Inversion of bedrock channel profiles in the Daqing Shan in Inner Mongolia, northern China: Implications for late Cenozoic tectonic history in the Hetao Basin and the Yellow River evolution. Tectonophysics 2020, 790, 228558. [CrossRef]

25. Jia, L.; Zhang, X.; Ye, P.; Zhao, X.; He, Z.; He, X.; Zhou, Q.; Li, J.; Ye, M.; Wang, Z.; et al. Development of the alluvial and lacustrine terraces on the northern margin of the Hetao Basin, Inner Mongolia, China: Implications for the evolution of the Yellow River in the Hetao area since the late Pleistocene. Geomorphology 2016, 263, 87-98. [CrossRef]

26. Fan, Y.; Wang, Y.; Mou, X.; Zhao, H.; Zhang, F.; Zhang, F.; Liu, W.; Hui, Z.; Huang, X.; Ma, J. Environmental status of the Jilantai Basin, North China, on the northwestern margin of the modern Asian summer monsoon domain during Marine Isotope Stage. J. Asian Earth Sci. 2017, 147, 178-192. [CrossRef]

27. Guo, X.; Forman, S.L.; Marin, L.; Li, X. Assessing tectonic and climatic controls for Late Quaternary fluvial terraces in Guide, Jianzha, and Xunhua Basins along the Yellow River on the northeastern Tibetan Plateau. Quat. Sci. Rev. 2018, 195, 109-121. [CrossRef]

28. Harkins, N.; Kirby, E.; Heimsath, A.; Robinson, R.; Reiser, U. Transient fluvial incision in the headwaters of the Yellow River, northeastern Tibet, China. J. Geophys. Res. Earth Surf. 2007, 112, 1-21. [CrossRef]

29. Li, J.; Fang, X.; Ma, H.; Zhu, J.; Pan, B.; Chen, H. Geomorphological and environmental evolution in the upper reaches of the Yellow River during the late Cenozoic. Sci. China Ser. D 1996, 26, 316-322. (In Chinese)

30. Wang, P.; Jiang, H.; Yuan, D.; Liu, X.; Zhang, B. Optically stimulated luminescence dating of sediments from the Yellow River terraces in Lanzhou: Tectonic and climatic implications. Quat. Geochronol. 2010, 5, 181-186. [CrossRef]

31. Pan, B.; Su, H.; Hu, Z.; Hu, X.; Gao, H.; Li, J.; Kirby, E. Evaluating the role of climate and tectonics during non-steady incision of the Yellow River: Evidence from a 1.24 Ma terrace record near Lanzhou, China. Quat. Sci. Rev. 2009, 28, 3281-3290. [CrossRef]

32. Shi, P.; Yang, T.; Tian, Q.; Jiang, S.; Fan, Z.; Wang, J. Loess record of climatic changes during MIS 12-10 in the Jingyuan section, northwestern Chinese Loess Plateau. Quat. Int. 2013, 296, 149-159. [CrossRef]

33. Yue, L.; Lei, X.; Qu, H. A magnetostratigraphic study on the Jingyuan loess section, Gansu, China. Quat. Sci. 1991, 11, 349-353. (In Chinese)

34. Wang, Z.; Nie, J.; Wang, J.; Zhang, H.; Peng, W.; Garzanti, E.; Hu, X.; Stevens, T.; Pfaff, K.; Pan, B. Testing Contrasting Models of the Formation of the Upper Yellow River Using Heavy-Mineral Data From the Yinchuan Basin Drill Cores. Geophys. Res. Lett. 2019, 46, 10338-10345. [CrossRef]

35. Voinchet, P.; Yin, G.; Falguères, C.; Liu, C.; Han, F.; Sun, X.; Bahain, J.J. Dating of the stepped quaternary fluvial terrace system of the Yellow River by electron spin resonance (ESR). Quat. Geochronol. 2019, 49, 278-282. [CrossRef]

36. Li, W.; Zhao, X.; Yang, Y.; Wu, Z. Formation Age and Provenance Analysis of the Gravel Layer in the Yellow River Terraces of the Hetao Basin. Acta Geosci. Sin. 2020, 41, 515-524. (In Chinese)

37. Liang, H.; Zhang, K.; Fu, J.; Li, S.; Chen, J.; Lu, K. The neotectonics in the Niushou Mountains, the northeastern margin of the Tibetan Plateau, China and its impact on the evolution of the Yellow River. Earth Sci. Front. 2013, 20, 182-189. (In Chinese)

38. Liu, Y. Neogene fluvial sediments in the northern Jinshaan Gorge, China: Implications for early development of the Yellow River since $8 \mathrm{Ma}$ and its response to rapid subsidence of the Weihe-Shanxi Graben. Paleogeogr. Paleoclimatol. Paleoecol. 2020, 546, 109675. [CrossRef]

39. Zhang, H.; Lu, H.; Zhou, Y.; Cui, Y.; He, J.; Lv, H.; Wang, K.; Wang, X. Heavy mineral assemblages and U Pb detrital zircon geochronology of sediments from the Weihe and Sanmen Basins: New insights into the Pliocene-Pleistocene evolution of the Yellow River. Paleogeogr. Paleoclimatol. Paleoecol. 2020, 562, 110072. [CrossRef]

40. Lin, A.; Yang, Z.; Sun, Z.; Yang, T. How and when did the Yellow River develop its square bend? Geology 2001, 29, 951. [CrossRef]

41. Guo, B.; Liu, S.; Peng, T.; Ma, Z.; Feng, Z.; Li, M.; Li, X.; Li, J.; Song, C.; Zhao, Z.; et al. Late Pliocene establishment of exorheic drainage in the northeastern Tibetan Plateau as evidenced by the Wuquan Formation in the Lanzhou Basin. Geomorphology 2018, 303, 271-283. [CrossRef]

42. Hu, Z.; Pan, B.; Guo, L.; Vandenberghe, J.; Liu, X.; Wang, J.; Fan, Y.; Mao, J.; Gao, H.; Hu, X. Rapid fluvial incision and headward erosion by the Yellow River along the Jinshaan gorge during the past 1.2 Ma as a result of tectonic extension. Quat. Sci. Rev. 2016, 133, 1-14. [CrossRef]

43. Hu, Z.; Pan, B.; Wang, J.; Cao, B.; Gao, H. Fluvial terrace formation in the eastern Fenwei Basin, China, during the past $1.2 \mathrm{Ma}$ as a combined archive of tectonics and climate change. J. Asian Earth Sci. 2012, 60, 235-245. [CrossRef] 
44. Li, Z.; Zhang, K.; Liang, H.; Chen, Z.; Li, X.; Khan, W.; Yu, Z.; Chen, Z.; Huang, P. Initial incision of the Jinshan Gorge of the Yellow River, China, constrained by terrestrial in situ cosmogenic nuclides chronology. Quat. Int. 2020, 550, 111-119. [CrossRef]

45. Liu, J.; Chen, X.; Shi, W.; Chen, P.; Zhang, Y.; Hu, J.; Dong, S.; Li, T. Tectonically controlled evolution of the Yellow River drainage system in the Weihe region, North China: Constraints from sedimentation, mineralogy and geochemistry. J. Asian Earth Sci. 2019, 179, 350-364. [CrossRef]

46. Pan, B.; Hu, Z.; Wang, J.; Vandenberghe, J.; Hu, X.; Wen, Y.; Li, Q.; Cao, B. The approximate age of the planation surface and the incision of the Yellow River. Paleogeogr. Paleoclimatol. Paleoecol. 2012, 356-357, 54-61. [CrossRef]

47. Zhang, J.; Wan, S.; Clift, P.D.; Huang, J.; Yu, Z.; Zhang, K.; Mei, X.; Liu, J.; Han, Z.; Nan, Q.; et al. History of Yellow River and Yangtze River delivering sediment to the Yellow Sea since 3.5 Ma: Tectonic or climate forcing? Quat. Sci. Rev. 2019, 216, 74-88 [CrossRef]

48. Fu, J.; Zhang, K.; Ma, Z.; Wang, S.; Wu, Y. The terrace (T5 and T4) formation since the late Middle Plestocene and its implication in the through cutting of the middle reach of Yellow River. Earth Sci. Front. 2013, 20, 166-181. (In Chinese)

49. Li, R. The relationship between developments of the Yellow River the Yongding River, and the evolution of fossil lake of drainage basin in the Cenozoic era. J. Beijing Norm. Univ. Nat. Sci. 1988, 4, 84-93. (In Chinese)

50. Wu, X.; Jiang, F.; Wang, S.; Xue, B. Regarding the problem of the Yellow River running through Sanmenxia and flowing into the sea. Quat. Sci. 1998, 18, 188. (In Chinese)

51. Wang, S.; Wu, X.; Zhang, Z.; Jiang, F.; Xue, B.; Tong, G.; Tian, G. Study on Environmental Changes Recorded by the Sediment of Sanmen Ancient Lake and the Yellow River Connecting Eastward. Sci. China Ser. D 2001, 31, 760-768. (In Chinese)

52. Meng, Y.; Zhang, J.; Qiu, W.; Fu, X.; Guo, Y.; Zhou, L. Optical dating of the Yellow River terraces in the Mengjin area (China): First results. Quat. Geochronol. 2015, 30, 219-225. [CrossRef]

53. Jiang, F.; Fu, J.; Wang, S.; Sun, D.; Zhao, Z. Formation of the Yellow River, inferred from loess-palaeosol sequence in Mangshan and lacustrine sediments in Sanmen Gorge, China. Quat. Int. 2007, 175, 62-70. [CrossRef]

54. Perrineau, A.; Woerd, J.V.D.; Gaudemer, Y.; Liu-Zeng, J.; Pik, R.; Tapponnier, P.; Thuizat, R.; Rongzhang, Z. Incision rate of the Yellow River in Northeastern Tibet constrained by 10 Be and $26 \mathrm{Al}$ cosmogenic isotope dating of fluvial terraces: Implications for catchment evolution and plateau building. Geo. Soc. Lond. Spec. Pub. 2011, 353, 189-219. [CrossRef]

55. Zhang, K.; Cai, J. Preliminary result of the dating by TCN technique of the highest terrace of the Heishanxia Gorge Mountain, northeast margin of Tibetan Plateau and its expression. Quat. Sci. 2006, 26, 85-91.

56. Pan, B.; Downs, W. Research upon the geomorphologic evolution of the Guide Basin and the development of the Yellow River. Arid Land Geogra. 1994, 7, 43-50.

57. Wang, S.; Jiang, F.; Fu, J.; Li, C.; Cai, Y.; Yao, H.; Qiao, Y.; Zhang, Z.; Li, Y. Some knowledge of the formation of the Yellow River. Quat. Sci. 2013, 33, 705-714. (In Chinese)

58. Han, J.; Shao, Z.; Zhu, D.; Meng, X.; Yu, W.J.; Lv, R.; Qian, C.; He, C. Characteristics of river terraces and formation of the Yellow River in the source region of Yellow River. Geol. China. 2013, 40, 1531-1541. (In Chinese)

59. Hilgendorf, Z.; Wells, G.; Larson, P.H.; Millett, J.; Kohout, M. From basins to rivers: Understanding the revitalization and significance of top-down drainage integration mechanisms in drainage basin evolution. Geomorphology 2020, 352, 107020. [CrossRef]

60. Lu, H.; An, Z. Experimental study on the influence of pretreatment methods on the grain size measurement of loess sediments. Sci. Bull. 1997, 42, 2535-2538. (In Chinese)

61. Zhang, H.; Lu, H.J.; Zhao, C.; Zhang, P. Effects of ultrasonic Dispersion on Granulometry of Fine-grain Loess. Acta Sedimentol. Sin. 2008, 26, 494-500. (In Chinese)

62. Vandenberghe, J.; Wang, X.; Lu, H. Differential impact of small-scaled tectonic movements on fluvial morphology and sedimentology (the Huang Shui catchment, NE Tibet Plateau). Geomorphology 2011, 134, 171-185. [CrossRef]

63. Paterson, G.A.; Heslop, D. New methods for unmixing sediment grain size data. Geochem. Geophys. Geosyst. 2016, 16, 4494-4506. [CrossRef]

64. Arason, P.; Levi, S. Maximum likelihood solution for inclination-only data in paleomagnetism. Geophys. J. Int. 2010, 182, 753-771. [CrossRef]

65. Lurcock, P.C.; Wilson, G.S. PuffinPlot: A versatile, user-friendly program for paleomagnetic analysis. Geochem. Geophys. Geosyst. 2012, 13, 1-6. [CrossRef]

66. Wang, X.; Ma, J.; Yi, S.; Vandenberghe, J.; Dai, Y.; Lu, H. Interaction of fluvial and eolian sedimentation processes, and response to climate change since the last glacial in a semiarid environment along the Yellow River. Quat. Res. 2019, 91, 570-583. [CrossRef]

67. Ogg, J.G. Chapter 5-Geomagnetic Polarity Time Scale. In The Geologic Time Scale; Gradstein, F.M., Ogg, J.G., Schmitz, M.D., Ogg, G.M., Eds.; Elsevier: Boston, MA, USA, 2012; pp. 85-113. ISBN 978-0-444-59425-9.

68. Ding, Z.L.; Derbyshire, E.; Yang, S.L.; Yu, Z.W.; Xiong, S.F.; Liu, T.S. Stacked 2.6-Ma grain size record from the Chinese loess based on five sections and correlation with the deep-sea $\delta 18 \mathrm{O}$ record. Paleoceanography 2002, 17, 1-5. [CrossRef]

69. Lu, H.; An, Z.; Wang, X.; Tan, H.; Zhu, R.; Ma, H.; Li, Z.; Miao, X.; Wang, X. Geomorphological evidence of the staged uplift of the northeastern margin of the Tibet Plateau in the recent 14 Ma. Sci. China Ser. D 2004, 34, 855-864. (In Chinese)

70. Wang, X.; Lu, H.; Vandenberghe, J.; Zheng, S.; van Balen, R. Late Miocene uplift of the NE Tibetan Plateau inferred from basin filling, planation and fluvial terraces in the Huang Shui catchment. Glob. Planet. Chang. 2012, 88-89, 10-19. [CrossRef] 
71. Miao, X.; Lu, H.; Li, Z.; Cao, G. Paleocurrent and fabric analyses of the imbricated fluvial gravel deposits in Huangshui Valley, the northeastern Tibetan Plateau, China. Geomorphology 2008, 99, 433-442. [CrossRef]

72. Zhang, J.; Li, J.; Guo, B.; Ma, Z.; Li, X.; Ye, X.; Yu, H.; Liu, J.; Yang, C.; Zhang, S.; et al. Magnetostratigraphic age and monsoonal evolution recorded by the thickest Quaternary loess deposit of the Lanzhou region, western Chinese Loess Plateau. Quat. Sci. Rev. 2016, 139, 17-29. [CrossRef]

73. Nugterrn, G.; Vandenberghe, J. Spatial climatic variability on the Central Loess Plateau (China) as recorded by grain size for the last 250 kyr. Glob. Planet. Chang. 2004, 41, 185-206. [CrossRef]

74. Yang, X.; Forman, S.; Hu, F.; Zhang, D.; Liu, Z.; Li, H. Initial insights into the age and origin of the Kubuqi sand sea of northern China. Geomorphology 2016, 259, 30-39. [CrossRef]

75. Vandenberghe, J. Grain size of fine-grained windblown sediment: A powerful proxy for process identification. Earth-Sci. Rev. 2013, 121, 18-30. [CrossRef]

76. Ma, J.; Wang, X.; Dai, Y.; Liu, Q.; Lu, H. Aeolian-fluvial Interplay History Recorded by Sediment Sequences from Huanghe Terrace in Semi-arid Environment During the Late Stage of Last Glacial Period. Geol. J. China Univ. 2017, 23, 750-758. (In Chinese)

77. Wang, X.; Yang, Z.; Løvlie, R.; Sun, Z.; Pei, J. A magnetostratigraphic reassessment of correlation between Chinese loess and marine oxygen isotope records over the last 1.1 Ma. Phys. Earth Planet. Inter. 2006, 159, 109-117. (In Chinese) [CrossRef]

78. Qiang, X.; Xu, X.; Chen, T.; Zhao, H.; Zheng, H. Spatial Distribution Characteristics and Influencing Factors of the Geomagnetic Polarity Reversal Boundary of Songshan-Burong. Quat. Sci. 2016, 36, 1125-1138. (In Chinese)

79. Yang, C.; Li, Y. The Principles of Geomorphology; Beijing University Press: Beijing, China, 2012; ISBN 9787301174869. (In Chinese)

80. Guo, Z.; Peng, S.; Hao, Q.; Chen, X.; Liu, D. Late Tertiary development of aridification in northwestern China: Link with the Arctic Ice-sheet formation and Tibetan uplifts. Quat. Sci. 1999, 19, 556-567. (In Chinese)

81. Lu, H.; Guo, Z. Evolution of the monsoon and dry climate in East Asia during late Cenozoic: A review. Sci. China-Earth Sci. 2013, 43, 1907-1918. (In Chinese) [CrossRef]

82. Liu, D.; An, Z.; Wen, Q.; Lu, Y.; Han, J.; Wang, J.; Diao, G. Geological environment of Chinese Loess. Sci. Bull. 1978, 23, 1-9. (In Chinese)

83. Liu, D.; Zheng, M.; Guo, Z. Initiation and evolution of the Asian Monsoon system timely coupled with the Ice-sheet growth and the tectonic movements in Asia. Quat Sci. 1998, 18, 194-204. (In Chinese)

84. Lu, H.; Zhang, F.; Liu, X.; Duce, R.A. Periodicities of palaeoclimatic variations recorded by loess-paleosol sequences in China. Quat. Sci. Rev. 2004, 23, 1891-1900. [CrossRef]

85. Ding, Z.; Liu, D. Processes of Loess research in China (part 1) Loess stratigeaphy. Quat. Sci. 1989, 9, 24-35. (In Chinese)

86. Ding, Z.; Sun, J.; Yang, S.; Xiong, S.; Gu, Z.; Liu, D.; Zhu, R.; Guo, B.; Yue, L. Magnetostratigraphy and grain size record of a thick red clay-loess sequence at Lingtai, the Chinese Loess Plateau. Quat. Sci. 1998, 18, 86-94. (In Chinese)

87. Ding, Z.; Yu, Z.; Liu, D. Process in Loess research (part 3): Time scale. Quat. Sci. 1991, 11, 336-348. (In Chinese)

88. Wang, N.; Li, Z.; Cheng, H.; Li, Y.; Huang, Y. High lake levels on Alashan Plateau during the Late Quaternary. Sci. Bull. 2011, 56, 1367-1377.

89. Dupont-Nivet, G.; Krijgsman, W.; Langereis, C.G.; Abels, H.A.; Dai, S.; Fang, X. Tibetan plateau aridification linked to global cooling at the Eocene-Oligocene transition. Nature 2007, 445, 635-638. [CrossRef]

90. Qinghai Bureau of Geology and Mineral Resources. Regional Geology of the Qinghai Province; Geology Publication House: Beijing, China, 1991; 662p. (In Chinese)

91. Pan, B.; Li, J.; Cao, J.; Chen, F. Study of the geomorphic evolution and development of the Yellow River in the Hualong Basin. Mount. Res. 1996, 14, 153-158. (In Chinese)

92. Gao, H.; Li, Z.; Ji, Y.; Pan, B.; Liu, X. Climatic and tectonic controls on strath terraces along the upper Weihe River in central China. Quat. Res. 2016, 86, 326-334. [CrossRef]

93. Gao, H.; Li, Z.; Liu, F.; Wu, Y.; Li, P.; Zhao, X.; Li, F.; Guo, J.; Liu, C.; Pan, B.; et al. Terrace formation and river valley development along the lower Taohe River in central China. Geomorphology 2020, 348, 106885. [CrossRef] 